\title{
CONFLICTS OF INTEREST IN GOVERNMENT CONTRACTS
}

Despite the tremendous growth of public contracting during the last quarter century ${ }^{1}$ and the continuous political controversy concerning the conflicting private and public interests of government officers, ${ }^{2}$ there is little modern critical writing on the conflict-of-interests law in this area. ${ }^{3}$ The absence of such writing and, at least in part, the recent drop in the volume of litigation ${ }^{4}$ may be attributed to the basic rules of law being regarded as settled and generally beyond criticism. Settled they may be; beyond criticism they are not.

Most jurisdictions have statutes ${ }^{5}$ and some have constitutional provisions ${ }^{6}$

${ }^{1}$ Consult James, The Protection of the Public Interests in Public Contracts 42 (1946); Hauser and Leonard, Government Statistics for Business Use 316 (1946); Walker, Public Administration in the United States 263 (1937).

2 Consult N.Y. Times, p. 1, col. 8 (July 15, 1955) (the resignation of Harold E. Talbot as Secretary of the Air Force); ibid., at p. 16, col. 5 (Oct. 27, 1955) (the resignation of Peter A. Strobel as Federal Commissioner of the Public Buildings Service). The controversy is not of recent origin. See Toronto v. Bowes, 4 Grant Ch. 489, 504 (1854).

${ }^{3}$ Only three treatises deal in detail with the subject: Rhyne, Municipal Contract Law (1952) (municipal contracts); James, op. cit. supra note 1 (municipal contracts); Shealey, The Law of Government Contracts (1938) (federal contracts). Consult also $10 \mathrm{McQuillen}$, Municipal Corporations $\$ 29.97$ (3d ed., 1950); 6 Williston, Contracts $\$ 1735$ (rev. ed., 1938). Law review material in point consists of: Kennedy and Beck, Interest of Public Officers in Contracts Prohibited by Law, 28 So. Cal. L. Rev. 335 (1955) (dealing exclusively with California law); The Disqualification of Administrative Officials, 41 Col. L. Rev. 1384 (1941); Local Contracts, 98 Just. P. 570 (1934); Ethical Standards in Government, 18 Alb. L. Rev. 276 (1934); Interest of Borough Councilman in Borough Contracts, 36 Dick. L. Rev. 202 (1932); Municipal Contracts and Disqualifications of Directors, 88 Just. P. 608 (1924); 35 Minn. L. Rev. 322 (1951), noting Henderson v. McCormick, 70 Ariz. 19, 215 P.2d 608 (1950); 23 Minn. L. Rev. 239 (1939), noting Miller v. Martinez, 28 Cal.App.2d 364, 82 P.2d 519 (1938); 20 Minn. L. Rev. 564 (1936), noting Mares v. Janutka, 196 Minn. 87, 264 N.W. 222 (1936); 17 Minn. L. Rev. 101 (1931), noting Wakely v. St. Louis, 184 Minn. 613, 240 N.W. 103 (1931).

4 For a chronological breakdown of cases consult note 44 infra.

- Where one of the following states has more than one provision, a single citation is given with an indication of the number of other such provisions. Code of Ala. (1940) c. 41, \$221; Cal. Gov't Code (1951) c. 1 , $\$ \$ 1090-92$; Colo. Rev. Stat. (1953) c. 40, $\$ \$ 19-5,9$; Gen. Stat. of Conn. (1949) c. 52, \$927; Fla. Stat. (1955) c. 283, \$283.02; Ga. Code Ann. (1935) c. 23, \$1713; Idaho Code (1948) c. 67, \$1622; Ill. Rev. Stat. (1955) c. 102, \$3; Ind. Stat. Ann. (Burns, 1933) c. $26, \$ 513$ (one); Code of Iowa (1954) c. 262, $\$ 10$ (seven); Gen. Stat. of Kan. (1949) c. 33, \$107 (four); Ky. Rev. Stat. Ann. (Baldwin, 1953) c. 160, \$160.180(4) (one); Rev. Stat. of Me. (1954) c. 135, \$17; Mich. Stat. Ann. (1952) c. 11, \$3.392 (two); Laws of Minn. (1955) c. $41, \$ 471.87$; Miss. Code Ann. (1942) $\$ \$ 2301-2$; Rev. Code of Mont. (1947) c. 59, $\$ \$ 501-3$; Nev. Comp. Laws (1929) $\S \S 4827-29$; Consol. Laws of N.Y. (McKinney, 1955 Supp.) c. 46, \$\$73-74; Gen. Stat. of N.C. (1953) c. 14, \$237 (one); Laws of N.D. (1955) c. 356 (two); Ohio Rev. Code \& Serv. (Baldwin, 1953) c. 29, \$2919.08; Pa. Stat. Ann. (Purdon, 1942) c. 71, \$196; S.D. Code (1939) c. 28, \$28-0221 (two); Utah Code Ann. (1953) c. 64, \$9-23 (three); Code of Va. (1950) c. 15, $\$ 504$ (one); Wis. Stat. (1953) c. 348, \$28. Consult also Exec. Order No. 9,001, 6 Fed. Reg. 6,787 (1941). For a compilation of statutory and constitutional provisions generally affecting public contracts consult James, op. cit. supra note 1 .

A municipal charter may also decree that no officer or employee shall contract with the city in his private capacity. Clover Hill Hospital, Inc. v. Lawrence, 315 Mass. 284, 52 N.E.2d 400 (1943); Stockton Plumbing \& Supply Co. v. Wheeler, 68 Cal.App. 592, 229 Pac. 1020 (1924).

- Where one of the following states has more than one provision, a single citation is given with an indication of the number of other such provisions. Colo. Const. Art. V, \$29; Ill. Const. 
forbidding officials ${ }^{7}$ from having a private interest in a public contract. There is, however, some variation with respect to the kinds of public servants falling within the prohibition, ${ }^{8}$ the type of private interest which proves offensive, ${ }^{9}$ which contracts (according to subject matter and amount) are condemned, ${ }^{10}$ and whether the interest is merely prohibited or the contract is voided. ${ }^{11}$ In some instances criminal penalties are also imposed..$^{12}$ By and large these statutes

Art. VIII, $\$ 4$; Ky Const. §247; La. Const. Art. III, §30; Miss. Const. Art. IV, §107; Mont. Const. Art. V, §30; Okla. Const. Art. V, §23; S.D. Const. Art. III, §12; Tex. Const. Art. III, $\$ 18$; W.Va. Const. Art. VI, $\$ 15$ (two); Wyo. Const. Art. III, $\$ 31$.

${ }^{7}$ In Southlands Co. v. San Diego, 211 Cal. 646, 297 Pac. 521 (1931), the California Supreme Court considered the following criteria in determining whether an individual was a public official: (a) regular and continuous service; (b) services not limited to a particular transaction; (c) fixed tenure or position; (d) liability to account for misfeasance or non-feasance; (e) receipt of compensation. These criteria would seem to be fairly representative of those used by other jurisdictions. See also Peabody v. Sanitary Dist. of Chicago, 330 Ill. 250, 256-60, 161 N.E. 519, 522-24 (1928); State ex rel. Aloe Instrument Co. v. Meier, 96 Mo.App. 160, 162-64, 69 S.W. 668,669 (1902).

${ }^{8}$ Compare Okla. Const. Art. V, $\$ 23$, prohibiting "members of the legislature," with Colo. Const. Art. V, $\$ 29$, prohibiting any "member or officer of any department of the government." The provisions also vary as to the responsibility involved in the letting of the contract. Compare Mich. Stat. Ann. (1952) c. 11, \$3.392, prohibiting the state "purchasing agent," with Ky. Rev. Stat. Ann. (Baldwin, 1955) c. 160, $\$ 160.180$, prohibiting "member of a board of education."

${ }^{9}$ Compare Consol. Laws of N.Y. (McKinney, 1955 Supp.) c. 46, \$73, exempting corporate interests of less than "ten per centum," with Gen. Stat. of Conn. (1949) c. 52, §927, prohibiting "any interest, direct or indirect."

${ }^{10}$ Compare Laws of N.D. (1955) c. 356, exempting contracts for a consideration of less than "ten thousand dollars in any one year," with Consol. Laws of N.Y. (McKinney, 1955 Supp.) c. 46, $\$ 73$, exempting contracts for less than "twenty-five dollars." Compare also Rev. Stat. of Me. (1954) c. $135, \$ 17$, prohibiting "any contracts ... of the state or of the institution or of [a] quasi-municipal corporation," with Pa. Stat. Ann. (Purdon, 1942) c. 71, \$196, prohibiting contracts for "stationery, printing, paper, fuel, furniture, materials or supplies ... or for the printing, binding, and distributing of the laws, journals, department reports, or any other printing and binding, or for the repairing and furnishing the halls and rooms used for the meetings of the General Assembly and its committees."

11 Compare Ill. Rev. Stat. (1955) c. 102, 3 , rendering the contract "null and void," with Laws of Minn. (1955) c. $41, \$ 471.87$, merely prohibiting any interest in a public contract.

12 Where one of the following states has more than one provision, a single citation is given with an indication of the number of other such provisions. Code of Ala. (1940) c. 41, \$211; Calif. Gov't Code (1951) c. 1, \$1097; Colo. Rev. Stat. (1953) c. 40, \$19-11; Gen. Stat. of Conn. (1949) c. 424, §8604; Ga. Code Ann. (1937) c. 89, $\$ 9915$ (one); Ill. Rev. Stat. (1955) c. 102, $\$ 4$ (two); Ind. Stat. Ann. (Burns, 1933) c. 10, $\$ 3713$ (two); Code of Iowa (1954) c. 18, \$4 (two); Gen. Stat. of Kan. (1949) c. 13, §533; Rev. Stat. of Me. (1954) c. 135, §17; Mich. Stat. Ann. (1952) c. 11, $\$ 3.392$ (two); Miss. Code Ann. (1942) $\$ \$ 2301-2$; Nev. Comp. Laws (1929) $\$ 4830$; Consol. Laws of N.Y. (McKinney, 1952) c. 39, \$1868; Ohio Rev. Code \& Serv. (Baldwin, 1953) c. 29, \$2919.08; Okla. Stat. (1951) c. 21, \$344; Pa. Stat. Ann. (Purdon, 1930) c. 16, $\S 64$; Utah Code Ann. (1953) c. 53, \$6-9; Wis. Stat. (1953) c. 348, §28.

A typical criminal statute is the one covering federal officers: "Whoever, being an officer, agent or member of, or directly or indirectly interested in the pecuniary profits or contracts of any corporation, joint-stock company, or association, or of any firm or partnership, or other business entity, is employed or acts as an officer or agent of the United States for the transaction of business with such business entity, shall be fined not more than $\$ 2,000$ or imprisoned not more than two years, or both." 62 Stat. 703 (1948), 18 U.S.C.A. $\$ 434$ (1950). 
and constitutional provisions are representative of the common law which voided the contract on grounds of public policy in order to protect the government from being defrauded by its own servants. ${ }^{13}$

While a few courts have upheld a contract coming within the legal prohibition when the officer could show that it was fair, entered into in good faith and bestowed no undue advantage or benefit, ${ }^{14}$ in most jurisdictions the existence of a disqualifying private interest renders the contract illegal per $\mathrm{se}^{15}$ and unenforceable as against public policy. ${ }^{16}$ The question of what constitutes a disqualifying interest is therefore pivotal.

In general, a disqualifying interest must be of a pecuniary character, ${ }^{17}$ friendship, sympathy or kinship being insufficient. ${ }^{18}$ The spousal relationship (par-

${ }^{13}$ E.g., Beakley v. Bremerton, 5 Wash.2d 670, 105 P.2d 40 (1940); Trainer v. Covington, 183 Ga. 759, 189 S.E. 842 (1937); McLain v. Miller County, 180 Ark. 828, 23 S.W.2d 264 (1930). Consult $10 \mathrm{McQuillen,} \mathrm{Municipal} \mathrm{Corporations} \$ 29.97$ (3d ed., 1950). See Veazey v. Allen, 173 N.Y. 359, 368, 66 N.E. 103, 106, declaring that to assist in the enforcement of contracts based on illegal activity would be to encourage conduct inimical to the public welfare. Consult also 6 Corbin, Contracts $\$ 1375$ (1951); Gellhorn, Contracts and Public Policy, 35 Col. L. Rev. 679, 685 (1935); Winfield, Public Policy in the English Common Law, 42 Harv. L. Rev. 76 (1928).

14 Grady v. Livingston, 115 Mont. 147, 41 P.2d 346 (1943); Concordia v. Hagaman, 1 Kan. App. 35, 41 Pac. 133 (1895); Spearman v. Texarkana, 58 Ark. 348, 24 S.W. 883 (1894); Pickett v. School Dist. No. 1, Town of Wiota, 25 Wis. 551 (1870); see Hartley v. Floete Lumber Co., 185 Iowa $861,864,171$ N.W. 183, 185 (1919).

${ }^{15}$ While the major commentators consider such contracts as a matter of "illegality," (6 Corbin, Contracts $\$ 1750$ [1951]; 6 Williston, Contracts $\$ 1735$ [rev. ed., 1938]; Rest., Contracts \$566 [1932]), most courts talk in terms of "void" or "voidable." Cases cited note 14 supra, and note 16 infra. The ordinary voidable contract can be avoided only by the innocent party, and is not subject to "cure" by the offending party. Because some courts permit the officer whose act created the defense to "cure" such contracts by showing they were fair, these contracts are really only "illegal if unfair" and are not properly considered under the voidvoidable analysis. 1 Corbin, Contracts $\$ 6(1950) ; 1$ Williston, Contracts $\$ 15$ (rev. ed., 1938). The rule of law applied by many of these same courts in situations where a conflict-of-interests exists between a corporation and its directors is correctly termed "voidable." Twin-Lick Oil Co. v. Marbury, 91 U.S. 587 (1875); Wyman v. Bowman, 127 Fed. 257 (C.A. 8th, 1904). See the dissenting opinion in Currie v. School Dist. No. 26, 35 Minn. 163, 167, 27 N.W. 922, 924 (1886) (urging application of corporate fiduciary principles to public officials).

${ }^{16}$ E.g., Crocker v. United States, 240 U.S. 74 (1916); Miller v. Martinez, 28 Cal.App.2d 364, 82 P.2d 519 (1938); Logan County v. Edwards, 206 Ky. 53, 266 S.W. 917 (1924); Minneapolis v. Canterbury, 122 Minn. 301, 142 N.W. 812 (1913); O'Neil v. Flannigan, 98 Me. 426, 57 Atl. 591 (1904); Snipes v. Winston, 126 N.C. 229, 35 S.E. 610 (1900). Consult 10 McQuillen, Municipal Corporations $\$ 29.97$ (3d ed., 1950).

17 E.g., Wis. Stat. (1953) c. 348, \$28; Mumma v. Brewster, 174 Wash. 112, 24 P.2d 438 (1933); Thompson v. School Dist. No. 1, 252 Mich. 629, 233 N.W. 439 (1930); Wilson v. New Castle, $301 \mathrm{~Pa} .358,152$ Atl. 102 (1930). Contra: Miller v. Martinez, 28 Cal.App.2d 364, 82 P.2d 519 (1938).

${ }^{18}$ E.g., Cunningham v. Union High School Dist., 131 Wash. 41, 228 Pac. 855 (1924); Edward E. Gillen Co. v. Milwaukee, 174 Wis. 362, 183 N.W. 679 (1921). Contra: Rankin v. Board of Education of Egg Harbor, 135 N.J.L. 299, 51 A.2d 194 (1947). In two jurisdictions statutes provide that kinsmen within a certain degree of a public officer shall not be interested in any contract with a governmental agency in which the relative is an officer. Ohio Rev. Code \& Serv. (Baldwin, 1953) c. 33, \$3319.21; Ky. Rev. Stat. Ann. (Baldwin, 1955) c. $160, \$ 160.180(4)$. 
ticularly in the community property states) ${ }^{19}$ individual proprietary, partnership, stockholder, directorship and employment interests all fall within the ban. ${ }^{20}$ The rule has even been carried to the extreme that ownership of one share of stock in a large corporation is a sufficient disqualifying interest.21 Where the official is a creditor of the private contracting party the decisions are closely divided, apparently turning on the part played by the official in the granting of the contract, his confidential or business relationship with the debtor and the presence of other factors tending to discourage competitors' attempts to procure the same contract. ${ }^{22}$

Where an interested party becomes a public officer after the execution of the contract, its validity is not impaired..$^{23}$ Similarly, an interest acquired subsequent to the letting of the contract does not invalidate $i^{24}$ unless a conspiracy between the private contractor and the official existed at the time of its execu-

19 Non-community property states: Githens v. Butler County, 350 Mo. 295, 165 S.W.2d 650 (1942); Haislip v. White, 124 W.Va. 633, 22 S.E. 2d 361 (1942); Nielson v. Richards, 75 Cal.App. 680, 243 Pac. 697 (1926). Community property states: Beakley v. Bremerton, 5 Wash.2d 670, 105 P.2d 40 (1940); School Dist. No. 302 v. Libby, 135 Wash. 233, 237 Pac. 505 (1925); Nuckols v. Lyle, 8 Idaho 589, 70 Pac. 401 (1902).

${ }^{20}$ Examples of cases where these interests have been found prohibitive include: Individual proprietary: Trainer v. Covington, 183 Ga. 759, 189 S.E. 842 (1937); Lillard v. Freestone County, 23 Tex.Civ.App. 363, 57 S.W.338 (1900); Partnership: Commonwealth ex rel. Kutz v. Witman, $217 \mathrm{~Pa}$. 411, 66 Atl. 986 (1907); Goodrich v. Waterville, 88 Me. 39, 33 Atl. 659 (1895); Stockholder: Norbeck \& Nicholson Co. v. State, 32 S.D. 189, 142 N.W. 847 (1913); Northport v. Northport Townsite Co., 27 Wash. 543, 68 Pac. 204 (1902); Directorship: State v. Robinson, 71 N.D. 463, 2 N.W.2d 183 (1942); Courtland v. Courtland Electric Co., 172 Minn. 392, 215 N.W. 673 (1927); Employment: Edward E. Gillen Co. v. Milwaukee, 174 Wis. 362, 183 N.W. 679 (1921); Byrne \& Speed Coal Co. v. Louisville, 189 Ky. 346, 224 S.W. 883 (1920). Membership in a non-profit association is usually not considered as a pecuniary interest. Furlong v. South Park Commissioner, 340 Ill. 363, 172 N.E. 757 (1930); Crawford v. Clifton Heights Borough, 11 Pa.Dist. 630 (1901). But cf. Wiesenthal v. Atlantic City, 73 N.J.L. 245, 63 Atl. 759 (S. Ct., 1906).

${ }^{21}$ Everett v. Griffiths, [1924] 1 K.B. 941; Foster v. Cape May, 60 N.J.L. 78, 36 Atl. 1089 (1897); cf. People ex rel. Schenectady Illuminating Co. v. Board of Sup'rs, 166 App.Div. 758, 151 N.Y.Supp. 1012 (3d Dep't, 1915). Recognizing the difficulty of determining the influence of ownership of a given quantity of stock, two states have enacted statutory provisions which fix the disqualifying interest at more than a certain percentage of the corporation's stock. Consol. Laws of N.Y. (McKinney, 1955 Supp.) c. 46, \$73; Laws of N.D. (1955) c. 356 (Initiated Measure, Approved June 29, 1954). Consult also Senate Bill 370, 2 Cal. Sen. J. 850 (1951), vetoed by Governor Warren, 3 Cal. Sen. J. 2790 (1951). The degree of interest that justifies wholesale condemnation is a difficult determination. The inquiry is not only concerned with "the effect of a particular transaction but whether its tendency is in the direction of public detriment." Fidelity \& Deposit Co. v. Grand Nat. Bank of St. Louis, 2 F.Supp. 666, 668 (E.D. Mo., 1933).

${ }^{22}$ Compare Tuscan v. Smith, 131 Me. 36, 153 Atl. 289 (1931), with Wilson v. New Castle, 301 Pa. 58, 152 Atl. 102 (1930).

${ }^{23}$ Harmison v. Prestonburg, 107 S.W. 337 (Ky., 1908); Beaudry v. Valdez, 32 Cal. 269 (1867).

${ }^{24}$ Martin Bros., Inc. v. Concord, 110 Cal.App.2d 215, 242 P.2d 406 (1952); Oakland v. California Const. Co., 15 Cal.2d 573, 104 P.2d 30 (1940); State ex rel. Great Falls Waterworks v. Great Falls, 19 Mont. 518, 49 Pac. 15 (1897). 
tion. ${ }^{25}$ On the other hand, where there is a disqualifying interest when the contract is formed, neither the official's subsequent resignation ${ }^{26}$ nor his disposal of the interest ${ }^{27}$ can give new life to the contract.

Once the requisite disqualifying interest is shown, the conflict-of-interests rule is rigidly applied..$^{28}$ Rarely is there any inquiry into whether or not personal influence actually was exercised in obtaining the contract. ${ }^{29}$ Some statutes and decisions do not even require the interested officer to have participated in the letting of the contract, his mere attachment to the public agency being sufficient to void the contract. ${ }^{30}$ Competitive bidding does not validate the contract, ${ }^{31}$ and an emergency is usually not considered as justifying a relaxation of the illegalper-se rule. ${ }^{32}$ Finally, there is generally no recovery in quantum meruit for the

${ }^{25}$ People v. Darby, 114 Cal.App.2d 412, 250 P.2d 743 (1952); People v. Deysher, 2 Cal.2d 141, 40 P.2d 259 (1935); Northport v. Northport Townsite Co., 27 Wash. 543, 68 Pac. 204 (1902).

${ }^{25}$ Philadelphia v. Durham, 16 Pa.Dist. 81 (1907); Dwight v. Palmer, 74 Ill. 295 (1874). The Oklahoma constitutional provision bars a public official from being interested in a government contract within two years after his term of office has expired. Okla. Const. Art. V, \$22. Ohio imposes criminal liability if the contract is made within one year after the officer's resignation. Ohio Rev. Code \& Serv. (Baldwin, 1953) c. 29, \$2919.10.

${ }^{27}$ Hardy v. Gainesville, 121 Ga. 327, 48 S.E. 921 (1904). But cf. Byrd v. Cook, 146 Ga. 657, 92 S.E. 61 (1917).

${ }^{28}$ Cases cited note 33 infra. That the government made an advantageous contract does not validate it. Stockton Plumbing \& Supply Co. v. Wheeler, 68 Cal.App. 592, 229 Pac. 1020 (1924); Norbeck \& Nicholson Co. v. State, 32 S.D. 189, 142 N.W. 847 (1913). Contra: Henderson v. McCormick, 70 Ariz. 19, 215 P.2d 608 (1950). Nor need the illegal contract have resulted in financial gain to the officer. People v. Darby, 114 Cal.App.2d 412, 250 P.2d 743 (1952); Miller v. Martinez, 28 Cal.App.2d 364, 82 P.2d 519 (1938).

${ }^{29}$ E.g., Crocker v. United States, 240 U.S. 74 (1916); Tool Co. v. Norris, 2 WVall. (U.S.) 45 (1864); Russell v. Courier Printing \& Publishing Co., 43 Colo. 321, 95 Pac. 936 (1908).

${ }^{30}$ E.g., Trainer v. Covington, 183 Ga. 759, 189 S.E. 842 (1937); Bristol v. Dominion Nat. Bank, 153 Va. 71, 149 S.E. 632 (1929). Contra: Niles v. Muzzy, 33 Mich. 61 (1875). For examples of some of the varying views: Ensley v. J. E. Hollingsworth \& Co., $170 \mathrm{Ala}$. 396, 54 So. 95 (1910), holding valid a contract free of fraud where the officer took no part in the letting; Marshall v. Ellwood City Borough, 189 Pa. 348, 41 Atl. 994 (1899), holding valid a contract where the officer's vote was not necessary for municipal approval; Sylvester v. Webb, 179 Mass. 236, 60 N.E. 495 (1901), holding valid a contract free from fraud where the officer cast the vote necessary for its authorization; Kennett Electric Light Co. v. Kennett Square, $4 \mathrm{~Pa}$. Dist. 707 (1894), intimating that a contract would be void even if the interested official had voted against it.

31 Trainer v. Covington, 183 Ga. 759, 189 S.E. 842 (1937); Capron v. Hitchcock, 98 Cal. 427, 33 Pac. 431 (1893); cf. Harrison v. Elizabeth, 70 N.J.L. 591, 57 Atl. 132 (S. Ct., 1904). Contra: Fla. Stat. (1955) c. 283, \$283.02; cf. Henderson v. McCormick, 70 Ariz. 19, 215 P.2d 608 (1950). State ex rel. Eaves v. Rickards, 16 Mont. 145, 40 Pac. 210 (1895) (semble). Exec. Order No. 9,001, 6 Fed. Reg. 6,787 (1941), has been interpreted to be unaffected by the letting of a contract on the basis of competitive bidding. Mitchell v. Flintkote Co., 185 F.2d 1008 (C.A. 2d, 1951).

${ }^{22}$ Wilson v. Montrose Borough, 12 Pa.Dist. 754 (1902); Ft. Wayne v. Rosenthal, 75 Ind. 156 (1881). But cf. Downs v. South Amboy, 116 N.J.L. 511, 185 Atl. 15 (1936). One court suggested that it would be willing to allow the contract to stand if an "extreme" emergency" existed but deny such relief when the emergency was only "ordinary." Byrne \& Speed Coal Co. v. Louisville, 189 Ky. 346, 224 S.W. 883 (1920).

Two apparent exceptions to the rule invalidating the contracts of an interested public 
luckless public official or the contracting firm in which he was interested, ${ }^{33}$ although a few cases have refused to allow the government to keep contract benefits without reimbursement. ${ }^{34}$

It is clear from the foregoing that the law is severe in its lack of concern as to whether or not the public official has in fact elevated his private interest above his public duty. To a certain extent this severity may be justified. The belief that the limitation on the private interests of public officers should be known and observed by those who deal with government, ${ }^{35}$ the popular concept that "a public office is a public trust" in tempting situations ${ }^{37}$ suggest the application of a strict conflict-of-interests rule. Moreover, the magnitude of government offers ample opportunity to conceal corrupt practices, thereby requiring a harsh deterrent.

The paucity of criminal prosecutions, evidenced by a quantitative comparison of the civil and criminal cases in this area, ${ }^{38}$ may indicate a failure of the criminal statutes to provide the necessary restraint. Thus, the severe civil law may also be justified, at least in part, by a need to supplement the criminal law because of difficulties inherent in the latter's application. One difficulty is that

official are: (1) where a higher level governmental authority instructs a governmental authority at a lower level to execute a contract with one of its own public officials; Kokomo v. State ex rel. Adams, 57 Ind. 152 (1877); Gibbons v. Mobile \& G. N. R. Co., 36 Ala. 410 (1860); and (2) where the official is interested in a company that is required to deal with the public body, such as a public utility. Hotchkiss v, Moran, 109 Cal.App. 321, 293 Pac. 148 (1930); Capital Gas Co. v. Young, 109 Cal. 140, 41 Pac. 869 (1895). But cf. People ex rel. Schenectady Illuminating Co. v. Board of Sup'rs, 166 App.Div. 758, 151 N.Y.Supp. 1012 (3d Dep't, 1915).

${ }_{33}$ Miller v. Martinez, 28 Cal.App.2d 364, 82 P.2d 519 (1938); Boca Raton v. Raulerson, 108 Fla. 376, 146 So. 576 (1933); Bristol v. Dominion National Bank, 153 Va. 71, 149 S.E. 632 (1929); Norbeck \& Nicholson Co. v. State, 32 S.D. 169, 142 N.W. 847 (1913). Consult the dissenting opinion of Justice Adair in Grady v. Livingston, 115 Mont. 47, 65, 141 P.2d 346, 355 (1943), where he lists a multitude of cases supporting this doctrine.

34 Grady v. Livingston, 115 Mont, 47, 141 P.2d 346 (1943); Hartley v. Floete Lumber Co., 185 Iowa 861,171 N.W. 183 (1919); Morse v. Board of Comm'rs of Granite County, 19 Mont. 450, 48 Pac. 745 (1877); cf. Call Publishing Co. v. Lincoln, 29 Neb. 149, 45 N.W. 245 (1890). The government cannot ratify the contract. E.g., Lincoln v. First Nat. Bank of Lincoln, 146 Neb. 221, 19 N.W.2d 156 (1945); Ferle v. Lansing, 189 Mich. 501, 155 N.W. 591 (1915). Contra: Green v. Stuart, 81 F.2d 968 (C.A. 5th, 1936); Fort Wayne v. Lake Shore \& M. S. Ry. Co., 132 Ind. 558, 32 N.E. 215 (1892).

${ }^{35}$ James, op. cit. supra note 1, at 4. "Men must turn square corners when they deal with the Government." Holmes, J., in Rock Island, A. \& L. R. Co. v. United States, 254 U.S. 141, 143 (1920). See also Federal Crop Ins. Corp. v. Merrill, 332 U.S. 380, 385 (1947).

${ }^{36}$ Consult 2 Dillon, Municipal Corporations $\$ 772$ (5th ed., 1911), for a discussion of public officers' fiduciary duties. Cf. Clapp, A Fiduciary's Duty of Loyalty, 3 Md. L. Rev. 221 (1939).

${ }^{37}$ See Cheney v. Unroe, 166 Ind. 550, 555, 77 N.E. 1041, 1043 (1906); Lum v. Clark, 56 Minn. 278, 282, 57 N.W. 662, 662-63 (1894); Waymire v. Powell, 105 Ind. 328, 332, 4 N.E. 886, 889 (1886); Greenhood, Public Policy $\$ 285$ (1886); cf. Contracts-Public Interest and Public Policy, 8 Ga. B. J. 324 (1946).

${ }^{38}$ Criminal prosecutions make up only 3 per cent of the appellate conflict-of-interests cases involving public officers. Consult note 44 infra. 
of proving criminal intent. ${ }^{39}$ In addition, while the civil prohibitions are construed against the contractor, the criminal statutes are construed strictly against the government..$^{40}$ Finally, where prosecutors owe their positions to the patronage of local officials, their interest in shielding the errant ways of their colleagues may sterilize the criminal law.

Notwithstanding the possible justifications for the strict conflict-of-interests rule, it is peculiarly subject to abuse. When combined with the taxpayers' suit, which is generally recognized as necessary to prevent corruption, the strict rule may become a weapon of political opportunists. ${ }^{41}$ This is suggested by the cases where the plaintiff-taxpayer's motives were called to account. ${ }^{42}$ The insignificant amount involved in many cases further tends to indicate that taxpayers' actions often are motivated more by considerations of politics than purse. ${ }^{43}$ Furthermore, a chronological breakdown of the cases shows that litigation during the hard times of the nineteen-thirties was more extensive than that of any other similar ten-year period. ${ }^{44}$ This uneven enforcement, highlighted by specific instances of abuse, ${ }^{45}$ indicates that municipalities may be using the harsh

${ }^{39}$ Criminal intent is a necessary element under the criminal statutes. State v. Robinson, 71 N.D. 463, 2 N.W.2d 183 (1942); State ex rel. Lawrenceburg v. Perkinson, 159 Tenn. 442, 19 S.W.2d 254 (1929); State v. Kuehnle, 85 N.J.L. 220, 88 Atl. 1085 (1913).

${ }^{10}$ Consult James, op. cit. supra note 1 , at 10.

11 In Henderson v. McCormick, 70 Ariz. 19, 215 P.2d 608 (1950), the taxpayer was the second-highest bidder on the proposed sale of a very old used truck which the city was willing to sell for around two hundred dollars. It is hard to see how the complainant could have suffered any loss as a taxpayer since his bid was fifty dollars less than the defendant public official's. Was the taxpayer really concerned with a breach of a duty, or was he merely attempting to "smear" the public official? See also Trainer v. Covington, $183 \mathrm{Ga} .759,189$ S.E. 842 (1937); Peet v. Leinbaugh, 180 Iowa 937, 164 N.W. 127 (1917).

For instances of abuse in actions arising in a different manner: State v. Robinson, 71 N.D. 463, 2 N.W.2d 183 (1942)(criminal prosecution); Marxer v. Saginaw, 270 Mich. 256, 258 N.W. 627 (1935) (suit on the contract which is an apparent attempt to absolve an official after a "smearing"); Douglas v. Pittman, 239 Ky. 548, 39 S.W.2d 979 (1931) (declaratory judgment on the right to hold a particular public office after ouster because of a charge of "interest" in a public contract); Logan County v. Edwards, $206 \mathrm{Ky} .53,266 \mathrm{S.W} .917$ (1924) (suit for recovery by city after change in administration); cf. Neisius v. Henry, 142 Neb. 29, 5 N.W.2d 291 (1942) (taxpayer's suit against surety of town officials). An excellent English case is Everett v. Griffiths, [1924] 1 K.B. 941.

12 In Everett v. Griffiths, [1924] 1 K.B. 941, 944, the court charged the plaintiff with making a practice of bringing "frequent, persistent, and fruitless litigation." For other cases where the motives are fairly obvious consult note 41 supra and note 43 infra.

43 E.g., State ex rel. Cochran v. Zeigler, 199 Iowa 392, 202 N.W. 94 (1925) (\$1.50); Peet v. Leinbaugh, 180 Iowa 937, 164 N.W. 127 (1917) (\$7.92); cf. Marxer v. Saginaw, 270 Mich. 256, 258 N.W. 627 (1935) (\$3.60).

"Over two hundred appellate cases involving the conflict-of-interests of public officials were selected in a random manner. The following percentages of cases arose during the tenyear periods:

$\begin{array}{lrllll}\text { Prior to } 1880 & 7 \% & 1900-1909 & 10 \% & 1930-1939 & 26 \% \\ 1880-1889 & 4 \% & 1910-1919 & 12 \% & 1940-1949 & 9 \% \\ 1890-1899 & 12 \% & 1920-1929 & 15 \% & 1950-1956 & 5 \%\end{array}$

${ }^{45}$ See, for instance, State ex rel. Great Falls Waterworks v. Great Falls, 19 Mont. 518, 529, 49 Pac. 15, 19 (1897), where the court accused the municipality of using the rigid application 
illegal-per-se rule as a means of avoiding burdensome contracts, rather than as a consistently applied deterrent against officials becoming interested in public contracts. ${ }^{46}$

Finally, to deny a public official not only his profits but also his $\operatorname{costs}^{47}$ has a penalizing as well as a restraining effect. Particularly where the interest is slight or indirect, subjecting an official or his business associates to large losses may result in disproportionate punishment, despite the absence of criminal liability; and given criminal liability, double punishment may result. ${ }^{48}$ Public policy would seem not well served by a rule which so obviously tends to discourage qualified men with wide private interests from entering public service. ${ }^{49}$ Thus, although it may sometimes be desirable to require injustice to particular individuals, ${ }^{50}$ the illegal-per-se rule would seem of dubious value if, in purporting to protect the government from being defrauded by its servants, it fosters improperly motivated governmental enforcement, political opportunism and

of the conflict-of-interests law as an excuse for repudiating a water contract which had become burdensome through changed financial conditions. Also examine Logan County v. Edwards, $206 \mathrm{Ky} .53,266$ S.W. 917 (1924).

${ }^{46}$ This type of abuse can hardly be considered as consistent with "democratic notions of the moral responsibility of the State." Mr. Justice Frankfurter dissenting in Kennecott Copper Corp. v. State Tax Commission, 327 U.S. 573, 580 (1946). See also Baltimore \& O. S. W. R. Co. v. Voigt, 176 U.S. 498, 505 (1900); Bartron v. Codington County, 68 S.D. 309, 323, 2 N.W.2d 337,344 (1942).

${ }^{47}$ Cases cited note 33 supra.

${ }^{48} \mathrm{Cf}$. Morris, The Relation of Criminal Statutes to Tort Liability, 46 Harv. L. Rev. 453, 469-70 (1933).

${ }^{49}$ Gellhorn, op. cit. supra note 13 , at 691 . The moral aspects of the problem cannot be solved by statutes such as the one recently enacted in North Dakota barring legislators from furnishing materials or services to the state or any of its subdivisions for a consideration in excess of ten thousand dollars in any one year. Laws of N.D. (1955) c. 356. The apparent object in providing such a limitation must have been to relieve the legislators of some of the more burdensome aspects of the present conflict-of-interests laws, possibly with a view to soliciting some of the state's more prosperous contractors as prospective legislators. But the amount involved would appear to have little if any relation to whether a conflict-of-interests in fact did constitute a detriment to the public's interest. In Lindberg v. Benson, -N.D. - 70 N.W. 2d 42 (1955), however, the North Dakota Supreme Court, in construing this statute indicated that size was a proper index to evil in these circumstances. "The greater the opportunity for profit, the greater is the temptation to venal acts...." Ibid., at 47 . In light of the court's interpretation of the statute it might just as well have said ninety thousand, instead of ten, for the court ruled that "any subdivision" meant "any one subdivision." Ibid., at 45. Compare the differing effect on one whose business necessitates contracting with a single department (e.g., a highway contractor), and one who deals with various governmental subdivisions (e.g., a fuel supplier). Similarly, compare the effect of the ten-thousand-dollar limitation on one who contracts infrequently but for large amounts (e.g., a building contractor), and one who contracts frequently for amounts less than the limitation (e.g., an office supply house). A New York statute places a maximum limit of twenty-five dollars. Consol. Laws of N.Y. (McKinney, 1955 Supp.) c. 46, $\$ 73$.

${ }^{50}$ See Baltimore \& O.S.W.R. Co.v. Voigt, 176 U.S. 498, 505 (1900), and Bartron v. Codington County, 68 S.D. 309, 323, 2 N.W.2d 337, 344 (1942), for considerations of the respective importance of fairness to the individual for society's betterment. Consult also Winfield, Public Policy in the English Common Law, 42 Harv. L. Rev. 76 (1928). 
overpunishment..$^{51}$

Furthermore, as presently understood and applied, the law would appear to be stricter than is otherwise necessary to achieve the purpose it was designed to serve. At least where the private interest is indirect, it is possible to argue that this purpose could adequately be accomplished if the conflict-of-interests rule was given only presumptive effect rather than being conclusive on the issue of illegality..$^{52}$ The public contract would then be unenforceable only if the privately contracting party could not prove fairness and good faith. It is doubtful that any in terrorem effect produced by the present strict rule would be lost if the burden of persuasion (and of coming forward) on these issues were placed on the privately contracting party. ${ }^{53}$ Whatever the posture of the litigants, ${ }^{54}$ this placement of the burden can easily be justified in terms of the considerations generally involved in the creation of legal presumptions. ${ }^{55}$ Present law undoubtedly reflects the probabilities of a lack of good faith and fairness, ${ }^{56}$ and the government may have meager access to facts proving their absence. It might also be advisable to apply a more rigid standard of proof than merely a "preponderance of evidence" in order to preserve the deterrent effect of the current law. ${ }^{57}$

${ }^{51}$ Perhaps the courts have simply not taken sufficient cognizance of the position that "he is the safest magistrate who is more watchful over the rights of the individual than over the convenience of the public, as that is the best government which guards more vigilantly the freedom of the subject than the right of the state." Kellogg v. Larkin, 3 Pin. 123, 137 (Wis., 1851). See also Electrical Contractors' Ass'n v. A. S. Schulman Electric Co., 391 Ill. 333, 33940, 63 N.E. $2 d$ 392, 395 (1945).

52 In support of the present rule, McQuillen states "that a contrary view would be disastrous to the public service." 10 McQuillen, Municipal Corporations $\$ 29.97$ (3d ed., 1950).

"53 The burdens of proof and persuasion on the question of whether or not an "interest" existed would remain with the party asserting the illegality of the contract.

${ }^{54}$ In connection with the statistical suvey mentioned in note 44 supra, it was determined these cases arise in the following manner:

$\begin{array}{lr}\text { Public official suing on contract } & 36 \% \\ \text { Taxpayer seeking to enjoin payment } & 24 \% \\ \text { Taxpayer seeking recovery for government } & 13 \% \\ \text { Government seeking recovery } & 10 \% \\ \text { Criminal prosecutions } & 3 \% \\ \text { Miscellaneous } & 14 \%\end{array}$

It was also found that 94 per cent of the cases arise at the local or municipal level of government, the remaining 6 per cent consisting mostly of state cases with but a few federal cases.

${ }^{55}$ The reasons which lead the courts to create presumptions are set forth in McCormick, Evidence $\$ 309$ (1954); Morgan and Maguire, Cases and Materials on Evidence 76 (1951). Consult also 9 Wigmore, Evidence $\$ \$ 2490-93$ (3d ed., 1940).

${ }^{58}$ The present law may indicate a feeling on the part of courts that the probability of corrupt practices is so high that a "conclusive presumption" must be created by barring all evidence as to the bona fides of the contract. Consult 9 Wigmore, Evidence $\$ 2492$ (3d ed., 1940).

57 Another possible standard would be that of "clear and convincing proof." Consult 9 Wigmore, Evidence $\$ 2498(2)$ (3) (3d ed., 1940), for a compilation of the instances in which this standard of persuasion is applied. The use in civil cases of the criminal standard, "beyond a reasonable doubt," is usually frowned upon. Ibid., at \$2497; May, Some 
There are few jurisdictions totally uncommitted to the illegal-per-se rule. In other states the law does not expressly require that public contracts in which an official is privately interested automatically be held void. Where precedent allows some freedom in dealing with the question and where legislative reexamination is possible, ${ }^{58}$ public policy would best be served by embracing a rule which, while preserving the in terrorem effect of the illegal-per-se rule, is more sensitive to the peculiarities of enforcement and not oblivious to the possibilities of good faith in the premises.

Reasonable Doubt in Civil and Criminal Laws, $10 \mathrm{Am}$. L. Rev. 642 (1875). The use of the criminal standard in this instance would be a complete innovation because the opponent, and not the proponent, of the issue of illegality would have to sustain this burden.

${ }^{58} \mathrm{As}$ to whose function it is to determine "public policy," compare these two contradictory statements: "[W] hen a court holds that a contract is valid or invalid, because it is or is not 'against public policy'... the question of what sound policy requires is plainly a judicial question"; 6 Corbin, Contracts $\$ 1375$ (1951); and "What does or does not represent the general interest is for the legislature to determine." Gellhorn, op. cit. supra note 13, at 685 . Generally, as to the function of the court in interpreting a statute that determines public policy, see Mr. Justice Frankfurter dissenting in United States v. Atlantic Mutual Ins. Co., 343 U.S. 236, 242 (1952).

\section{VALUATION IN CONDEMNATION: THE TWIN CITY POWER CASE}

In condemnation proceedings the Fifth Amendment" requirement of "just compensation" has generally been interpreted to be the market value at the time of taking. ${ }^{2}$ In the recent case of United States v. Twin City Power Co., ${ }^{3}$ the Supreme Court, in a five to four decision, departed from this standard in holding that the increment in the value of riparian lands due to their suitability as a power site was not compensable when the United States was the condemnor. The majority opinion contains no reference to market value, or to any other standard, and the issue is stated simply in terms of whether or not the "United States must pay ... the value of the land as a site for hydroelectric power operations."4

In reaching its decision, the Court relied solely on United States v. ChandlerDunbar Co. ${ }^{5}$ which was a condemnation proceeding brought by the United

1 U.S. Const. Amend. 5.

2 Consult 4 Nichols, Eminent Domain $\$ 12.1$ (3d ed., 1951); 1 Orgel, Valuation under Eminent Domain $\$ 17$ (2d ed., 1953), and cases there cited.

3350 U.S. 222 (1956).

4 Tbid., at 223.

5229 U.S. 53 (1913). In its brief the government also relied on three lawer court cases. Washington Water Power Co. v. United States, 135 F.2d 541 (C.A. 9th, 1943); Continental Land Co. v. United States, 88 F.2d 104 (C.A. 9th, 1937); United States v. West Virginia Power Co., 56 F.Supp. 298 (S.D. W.Va., 1944). The first two cases can be read, however, to fall within the established doctrine that compensation will not be allowed for uses which are too remote or speculative. 